\title{
The Relationship of Regular Exercise and Diet with Degenerative Diseases Among the Residents of Housing Kanjuruhan Asri, Malang City
}

\section{Galih Sapto Adi, Rias Gesang Kinanti, and Andiana Olivia}

Department of Sport Science, Faculty of Sport Science, Universitas Negeri Malang, Malang, Indonesia

ORCID:

Olivia Andiana: https://orcid.org/0000-0002-1880-925X

\section{Abstract}

This study aims to find out both partially and simultaneously the relationship of Exercise Regularity $\left(X_{1}\right)$ and Diet $\left(X_{2}\right)$ with the Incidence of Degenerative Diseases (Y) among the residents of Housing Kanjuruhan Asri, Malang City. The study uses a purposive proportional random sampling survey method. The instrument of the study

Corresponding Author: Rias Gesang Kinanti rias.gesang.fik@um.ac.id

Published: 25 March 2021

Publishing services provided by Knowledge E

(c) Galih Sapto Adi et al. This article is distributed under the terms of the Creative Commons Attribution License, which permits unrestricted use and redistribution provided that the original author and source are credited.

Selection and Peer-review under the responsibility of the ISMoPHS 2020 Conference Committee. was a questionnaire that has previously been validated by the Pearson's Product Moment validity test and Spearman Brown's reliability test (Split Half). Data were analysed using the Spearman's Rank and Multiple Correlation techniques. The results showed that Regularity of Exercise $\left(X_{1}\right)$ had a correlation coefficient of 0.881 and Diet $\left(X_{2}\right)$ a correlation coefficient of 0.963 with the Degenerative Disease Incidence $(Y)$. Also, Regularity of Exercise $\left(X_{1}\right)$ and Diet $\left(X_{2}\right)$ had a simultaneous relationship with degenerative disease incidence $(Y)$ with a correlation coefficient of 0.966 . The results of the Coefficient of Determination $\left(R^{2}\right)$ test of 0.932 explained the contribution of the influence of the variables Exercise Regularity $\left(X_{1}\right)$ and Diet $\left(X_{2}\right)$ to the variable Degenerative Disease Incidence $(Y)$ of $93.2 \%$; which is quite high. Therefore, it is concluded that there is a significant relationship both partially and simultaneously between Exercise Regularity $\left(X_{1}\right)$ and Diet $\left(X_{2}\right)$, and the Incidence of Degenerative Diseases $(\mathrm{Y})$ among the residents of Housing Kanjuruhan Asri, Malang City.

Keywords: regularity sport, diet, degenerative diseases, questionnaire

\section{Introduction}

Degenerative diseases are non-communicable diseases caused by decreased organ function due to the aging process [1]. At this time, the degenerative disease is the main disease that causes death in the world [2]. In Indonesia the incidence of degenerative diseases, namely stroke by 1.236 .825 people, as many as 84.345 people hypertension, 
and 330.000 cancer. The increasing prevalence of degenerative diseases become fundamental issues for the people of Indonesia.

Degenerative disease began to attack at the age of 30 years, at the age increase the risk of degenerative diseases. Degenerative disease is not only lethal, but it also requires a considerable cost. This degenerative disease can also affect the quality of life of the sufferer. In addition, a decrease in cell function can also occur in degenerative diseases [3]. Degenerative diseases include coronary heart disease (CHD), diabetes mellitus, stroke, hypertension [4].

Hypertension is a primary factor in heart disease and stroke. Currently hypertension is the third biggest risk factor for premature death. Hypertension causes $62 \%$ of cardiovascular disease and $49 \%$ of heart disease. This disease kills 9.4 million people in the world every year [5]. Hypertension is greater in active and passive smokers as well but is low. In some cases, obesity as a result of unbalanced nutritional intake and lack of exercise can increase the risk of hypertension [6]. In addition, obesity is also associated with type 2 diabetes mellitus [7].

Degenerative diseases can be prevented by minimizing the risk factors causing them. For example, changes in lifestyle towards food consumption, this is mainly triggered by an increase in the economic income sector, high work activities and consuming fast food, but this is not balanced with good nutrition knowledge. This causes the food culture to change to be high in saturated fat and sugar, low in fibre and low in micronutrients. In addition, changes in socio-economic and appetite will result in changes in people's eating patterns that tend to keep the concept of a balanced diet away, thus having a negative impact on health and nutrition. An irregular diet, saturated fat and sugar, low in fibre and low in micronutrients will cause obesity problems, excess nutrition, and increase free radicals, which in turn result in a change in disease patterns from infection to chronic non-infectious diseases or the emergence of degenerative diseases [3]. The main cause of degenerative diseases is an unhealthy lifestyle such as smoking, drinking alcohol, stress, environmental pollution, obesity, diet, and regular exercise [8].

Other research states that regular exercise with complications of type 2 diabetes is significant. There is a significant relationship between exercise status and the incidence of hypertension in patients aged 45 years and over at Kedurus Health Centre Surabaya in 2015 [9]. In addition, based on previous research, there is a relationship between diet and type 2 diabetes. However, the correlation between exercise regularity and dietary patterns with degenerative diseases is still unclear. On the basis of this background, it is necessary to re-conduct research on the correlation of regular exercise and diet with degenerative diseases. 


\section{Material and Method}

This study used a descriptive survey approach with a correlational research design with a quantitative approach, with a cross sectional study design [10]. The population in this study were all residents of Kanjuruhan Asri Housing Malang City, amounting to 82 people. The research sample was determined based on purposive proportional random sampling, namely males aged over 45 years and experiencing degenerative disease incidents in order to obtain a total sample of 50 people. The data was collected using a questionnaire instrument from three variables, each of which is Regular Exercise $\left(X_{1}\right)$, Diet $\left(X_{2}\right)$ and Degenerative Diseases $(Y)$. Data analysis and hypothesis testing were carried out using the Spearman Rank correlation technique and multiple correlation followed by the calculation of the coefficient of determination $\left(R^{2}\right)$.

\section{Results}

\subsection{Spearman's Rank Correlation Test}

The Spearman Rank correlation test was carried out in order to determine the level of the relationship between each independent variable and the dependent variable, namely the relationship between each variable Exercise Regularity $\left(X_{1}\right)$ and Diet Variable $\left(\mathrm{X}_{2}\right)$ with Degenerative Disease Incidence $(\mathrm{Y})$. Decision making is determined based on criteria if the value is sig. greater than the significance level $(p<0.05)$ then Ho is accepted, which means that there is a significant relationship between the independent variable and the dependent variable. An overview of the results of the Spearman Rank correlation test can be seen below.

TABLE 1: Overview of the Spearman Rank Correlation test results.

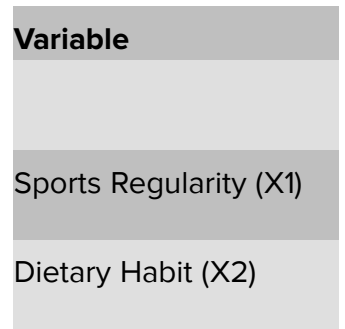

\begin{tabular}{|c|}
\hline Incidence of degen \\
Correlation \\
Coefficient $(\rho)$ \\
0.881 \\
0.919 \\
\hline
\end{tabular}

Sig. (2-tailed)
0.000
0.000

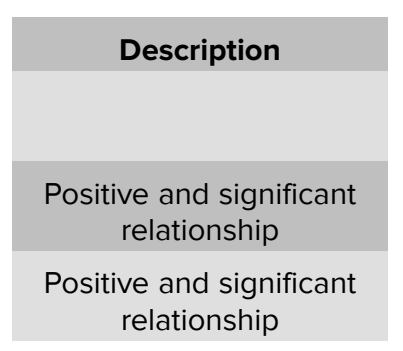

Source: Author's own work.

The results of the Spearman Rank Correlation test as in the summary above can be explained as follows. 


\subsubsection{Spearman Rank Correlation Test Results and Hypothesis Testing of Regular Exercise Variables (X1) with Degenerative Disease Inci- dence Variable (Y)}

The results of the Spearman Rank correlation test for the Exercise Regularity variable $\left(X_{1}\right)$ and the Degenerative Disease Incidence $(Y)$ variable show that the Spearman Rank correlation coefficient is 0.881 at the probability level of 0.000 . As the predetermined criteria, this states that the calculated probability value (sig) $<0.05$ so that $\mathrm{Ho}$ is accepted and $\mathrm{Ha}$ is rejected, which means that there is a significant correlation between Exercise Regularity $\left(X_{1}\right)$ and Degenerative Disease Incidence $(Y)$. Thus the research hypothesis which states that there is a significant relationship between Exercise Regularity $\left(X_{1}\right)$ and Degenerative Disease Incidence $(\mathrm{Y})$ variables can be accepted or verified. The Spearman Rank correlation coefficient value of 0.881 is in the range of $0.800-1,000$ so that the level of the relationship that occurs between the Exercise Regularity variable $\left(X_{1}\right)$ and the Degenerative Disease Incidence variable $(Y)$ is in the very strong category.

\subsubsection{Spearman Rank Correlation Test Results and Hypothesis Test for Diet Variables (X2) with Variable Incidence of Degenerative Dis- eases $(Y)$}

The results of the Spearman Rank correlation test for the Diet variable $\left(\mathrm{X}_{2}\right)$ with the Degenerative Disease Incidence $(Y)$ variable showed the Spearman Rank correlation coefficient of 0.919 at the probability level of 0.000 . As the predetermined criteria, this states that the calculated probability value (sig) $<0.05$ so that $\mathrm{Ho}$ is accepted and $\mathrm{Ha}$ is rejected, which means that there is a significant correlation between the Diet variable $\left(\mathrm{X}_{2}\right)$ and the Degenerative Disease Incidence $(\mathrm{Y})$ variable. The Spearman Rank correlation coefficient value of 0.919 is in the range between $0.800-1,000$ so that the level of the relationship between the Diet variable $\left(X_{2}\right)$ and the Degenerative Disease Incidence variable $(\mathrm{Y})$ is included in the Very Strong category.

\subsection{Multiple correlation test}

Multiple correlation testing aims to determine the simultaneous relationship of the variable exercise regularity $\left(X_{1}\right)$ and dietary pattern $\left(X_{2}\right)$ with the Variable incidence of degenerative disease $(\mathrm{Y})$. Decision making is determined based on criteria if the value is sig. $F$ is smaller than the significance level $(p<0.05)$, then the two independent variables have a significant relationship with the dependent variable, whereas if the 
value is sig. $F$ is greater than the significance level $(p>0.05)$, so the two independent variables do not have a significant relationship with the dependent variable (Ghozali, 2015). The result of multiple correlation testing aims to determine the simultaneous relationship between Exercise Regularity $\left(X_{1}\right)$ and Diet $\left(X_{2}\right)$ Variables with Degenerative Disease Incidence Variables (Y).

TABLE 2: Multiple correlation test results.

\begin{tabular}{|l|l|l|l|l|l|}
\hline Model & \multicolumn{4}{|c|}{ R } & \multicolumn{3}{|c|}{ Change statistics } \\
\hline & F Change & df1 & df2 & $\begin{array}{c}\text { Sig. F } \\
\text { Change }\end{array}$ \\
\hline 1 & $0.966^{a}$ & 324.581 & 2 & 47 & 0.000 \\
\hline
\end{tabular}

Predictors: (Constant), dietary habit $\left(\mathrm{X}_{2}\right)$, sports regularity $\left(\mathrm{X}_{1}\right)$.

The results of the multiple correlation test above show the correlation value (R) of 0.966 and a significance of $F$ of 0.000 . Sig value. $F$ is smaller than the significance level $(0.000<0.05)$, so $\mathrm{Ho}$ is accepted and $\mathrm{Ha}$ is rejected, which means that there is a significant relationship simultaneously variable Exercise Regularity $\left(X_{1}\right)$ and Diet $\left(X_{2}\right)$ with Degenerative Disease Incidence Variable (Y). 0.966 explains that the relationship between the two independent variables and the dependent variable is included in the very strong relationship category.

\subsection{Coefficient of determination (R2)}

The coefficient of determination $\left(\mathbf{R}^{2}\right)$ has a meaning as a contribution to the influence given by the variable exercise regularity $\left(X_{1}\right)$ and dietary pattern $\left(X_{2}\right)$ on the variable incidence of degenerative diseases $(Y)$. The requirements that must be met in order to interpret the coefficient of determination are that the F-test value is significant. The results of the determination coefficient $\left(\mathbf{R}^{2}\right)$ test can be seen in the following table.

TABLE 3: Determination coefficient test results.

\begin{tabular}{|l|c|c|c|c|c|}
\hline Model & R & R Square & $\begin{array}{c}\text { Adjusted R } \\
\text { Square }\end{array}$ & $\begin{array}{c}\text { Std. Error of } \\
\text { the Estimate }\end{array}$ & $\begin{array}{c}\text { Sig. F } \\
\text { Change }\end{array}$ \\
\hline 1 & $0.966^{a}$ & 0.932 & 0.930 & 0.247 & 0.000 \\
\hline
\end{tabular}

Predictors: (Constant), dietary habit $\left(\mathrm{X}_{2}\right)$, sports regularity $\left(\mathrm{X}_{1}\right)$.

The result of the coefficient of determination $\left(R^{2}\right)$ shows that the coefficient of determination $\left(R^{2}\right)$ is 0.932 . This confirms that the contribution of the influence of the variable exercise regularity $\left(X_{1}\right)$ and diet $\left(X_{2}\right)$ on the variable incidence of degenerative diseases $(Y)$ is $93.2 \%$. The value of the coefficient of determination $\left(R^{2}\right)$ of 0.932 states that 
regular exercise $\left(X_{1}\right)$ and diet $\left(X_{2}\right)$ have a very high contribution to the incidence of degenerative diseases $(Y)$.

\section{Discussion}

\subsection{The relationship between regular exercise and degenerative disease incidence}

The results of this study indicate that there is a significant relationship between regular exercise and the incidence of degenerative disease with a very strong level of association. The results of this study are consistent with the results of research conducted by Putri Astuti (2016) stated that there is a relationship between regular exercise and complications of type 2 diabetes [9]. The results of this study also support the results of Putri Astuti (2016), which states that there is a significant relationship between exercise status and the incidence of hypertension in patients aged 45 years and over [9].

The results of this study are in line with the opinion that exercise can help reduce blood pressure so there is no need to take blood pressure-lowering drugs. Exercise will help drugs work more effectively in people with hypertension who must take medication [11]. In the elderly starting at the age of 45 years, regular exercise has been shown to improve cardiovascular function which slows down the decline in body function [12].

Unhealthy lifestyles such as irregularities in exercise are one of the main causes of degenerative diseases [8]. Exercising regularly at least 3-5 times a week has a positive impact in reducing the risk of degenerative diseases. This is because regular exercise is related to the duration and frequency of exercise that must be done, for example 3 times a week or 5 times a week and must be done regularly and continuously [13].

\subsection{The relationship between diet and degenerative disease}

The results showed that there was a significant relationship between diet and the incidence of degenerative diseases with a very strong level of relationship. The results of this study are consistent with the previous research concluded that in their research there was a relationship between diet and type 2 diabetes. The results of this study also supported the results of the research by Tokunaga et al. (2012) which states that dietary factors may trigger inflammatory dysfunction in the tissues, leading to central obesity and overweight which triggers central obesity and overweight which is a risk factor for degenerative diseases [14]. 
Diet is an individual way of regulating the amount, frequency and type of food with a specific purpose to maintain health, nutritional status, prevent or help cure disease [15]. The right diet can reduce the risk of diabetes. Diet should be adjusted to the body's biological clock because it is closely related to hormones that work at certain hours.

\subsection{Relationship between regular exercise and diet and the inci- dence of degenerative diseases}

The results of this study indicate that there is a simultaneous significant relationship between exercise regularity and diet with the incidence of degenerative disease. This result is in line with the opinion that the main cause of degenerative disease is an unhealthy lifestyle such as smoking, drinking alcohol, stress, environmental pollution, obesity, eating patterns, and irregularity in exercise [8]. Efforts to prevent degenerative diseases can be done, among others, by changing lifestyles, overcoming obesity, controlling stress, doing physical activity and exercising regularly, and adopting a balanced nutritional diet [16].

Changing your lifestyle is the key to the success of preventing degenerative diseases. Lifestyle changes or changes in habits include three important things, namely: diet, physical activity, and changes in habits. One important thing that needs to be considered in changing lifestyle is trying to stay away from toxic environments, such as instant food, eating high calorie rich in fat, fast food, soft drinks, and so on [16].

Overcoming obesity, can be done by making a commitment to losing weight, thinking positively by concentrating on the progress achieved, determining priority scales, making realistic targets, and controlling body weight [16].

Controlling stress due to stress has a considerable influence on the body's metabolic system because it will deplete vitamins and minerals. Stress stimulates the release of the hormone adrenaline excessively, meanwhile, to produce this hormone, B vitamins, minerals, zinc, potassium and calcium are needed [16].

Doing physical activity and exercise regularly. Physical activity is all muscle movements that burn body energy, while exercise is a rhythmic and regular body movement to improve and improve fitness [16].

Implementing a balanced nutritional diet, balanced nutrition means that the amount of nutrients (food) consumed must be proportional to the number of nutrients released. Nutrients include carbohydrates, fats, proteins, vitamins, minerals and water. Carbohydrates, fats and proteins are the main components of energy fulfilment in addition to their respective main functions. The body requires sufficient energy which can be 
monitored through changes in body weight at any time (day / week). Meanwhile, the composition of nutrients for energy sources ideally consists of $60-70 \%$ carbohydrates, $20-25 \%$ fat, and $10-15 \%$ protein [16].

\section{Conclusion}

On the basis of the discussion of the relationship between regular exercise and eating patterns with the incidence of degenerative diseases as previously described, the following conclusions can be drawn. There is a significant correlation between Exercise Regularity (X1) and Degenerative Disease Incidence (Y). There is a significant relationship between Diet (X2) and Degenerative Disease Incidence variable (Y). There is a significant relationship simultaneously Exercise Regularity (X1) and Diet (X2) with the Incidence of Degenerative Disease.

\section{Acknowledgement}

None.

\section{Conflict of Interest}

There is no conflict of interest.

\section{References}

[1] Berawi, K., N., Wahyudo, R. and Pratama, A. A. (2019). Potensi Terapi Moringa oleifera (Kelor) pada Penyakit Degeneratif. Jurnal Kedokteran Universitas Lampung, vol. 3, issue 1, pp. 210-14.

[2] Rochmawati, E. (2019). Pencegahan Penyakit Degeneratif Melalui Gerakan Sehat Berbasis Masjid (Rehatsimas). Jurnal Pengabdian dan Pemberdayaan Masyarakat, vol. 3, issue 2, pp. 265-71.

[3] Dhani, S. R. and Yamasari, Y. (2014). Rancang Bangun Sistem Pakar Untuk Mendiagnosa Penyakit Degeneratif. Jurnal Manajemen Informatika, vol. 3, issue 2, pp. 17-25.

[4] Boehme, A. K., Esenwa, C. and Elkind, M. S. V. (2017). Stroke Risk Factors, Genetics and Prevention. Circulation Research, issue 120, pp. 472-95. 
[5] Muliani, B. (2016). Hubungan Pola Makan, Asupan Makanan Dan Obesitas Sentral dengan Hipertensi Di Puskesmas Rajabasa Indah Bandar Lampung. Jurnal Kesehatan, vol. 7, issue 1, pp. 34-45.

[6] Sartika, R. M., Tjekyan, S. and Zulakarnain, M. (2017). Faktor - Faktor Risiko Dan Angka Kejadian Hipertensi pada Penduduk Palembang. Jurnal IImu Kesehatan Masyarakat, vol. 8, issue 3, pp. 180-91.

[7] Nasution, L. K., Siagian, A. and Lubis, R. (2018). Hubungan Obesitas Terhadap Kejadian Diabetes Melitus Tipe 2 Pada Wanita Usia Subur Di Wilayah Kerja Puskesmas Pintu padang. Jurnal Muara Sains, Teknologi, Kesehatan, dan IImu Kesehatan, vol. 2, issue 1, pp. 240-6.

[8] Handajani, A., Roosihermiatie, B. and Maryani, H. (2010). Faktor-Faktor Yang Berhubungan Dengan Pola Kematian Pada Penyakit Degeneratif Di Indonesia. Buletin Penelitian Sistem Kesehatan, vol. 13, issue 1, pp. 42-53.

[9] Putriastuti, L. (2016). Analisis Hubungan Antara Kebiasaan Olahraga Dengan Kejadian Hipertensi Pada Pasien Usia 45 Tahun Keatas. Jurnal Berkala Epidemiologi, vol. 4, issue 2, pp. 225-36.

[10] Lloyd, C., Smith, J. and Weinger, K. (2005). Stress and Diabetes: A Review of the Links. Diabetes Spectrum, vol. 18, issue 2, pp. 121-7.

[11] Sheps, G. S. (2005). Mayo Clinic Hipertensi Mengatasi Tekanan Darah Tinggi. Jakarta: PT. Intisari Mediatama.

[12] Afriwardi, A. (2009). Ilmu Kedokteran Olahraga. Jakarta: Penerbit Buku Kedokteran EGC.

[13] Sugiharto, S. (2014). Fisiologi Olahraga: Teori dan Aplikasi Pembinaan Olahraga. Malang: Universitas Negeri Malang.

[14] Tokunaga, M., Takahashi, T. and Singh, R. B. (2012). Diet, Nutrients and Noncommunicable Disease. The Open Nutraceuticals Journal, vol. 5, issue 1, pp. 146-59.

[15] Harper, L. J. S. (2003). Pangan dan Gizi: Pola Makan. Jakarta: Universitas Indonesia Press.

[16] Suiraoka, I.P. (2012). Penyakit Degeneratif: Mengenal, Mencegah dan Mengurangi Faktor Risiko 9 Penyakit Degeneratif. Yogyakarta: Medical Book. 